\title{
Need to Update of Irrigation and Water Resources Information According to the Progresses of Agricultural Knowledge
}

\section{Mohammad Valipour*}

Department of Irrigation and Drainage Engineering, College of Abureyhan, University of Tehran, Iran

\section{Editorial}

The role of the farmer changes from season to season. Like the fields they plant or the livestock they raise, no season, and no farm operation, is the same. Implementation of emerging technology is one thing setting several farming operations apart from their competition, whether crop farms, dairy farms or livestock farms. Much like other commercial industries, agriculture has been on the receiving end of new and evolving technologies that make life on the farm easier while increasing efficiency and decreasing costs. New farm technology ranges from the simplest smart phone app that turns an iPod into a mobile milk-monitoring station or allows farmers to record herd information from the field to the hundreds of thousands of dollars that may be spent on precision planting equipment. The demand and need for new technologies have largely been increased in the world. One of the most progressed technologies is about genetics, genomics and genetic modification in agriculture [1-4]. Large scale planting systems are increasingly being used to boost production. These mechanical devices work better when the shape of the seed is more uniform; the seeds "flow better" in a mechanical sense. Pelleting caters to this type of requirement, by creating round pellets of a standardized size. Besides this plantability issue, there are multiple other reasons to use a pellet: use of phototoxic products, weight and/or volume increase, addition of biological control agents, and growth promoting agents. Pesticides and fungicides have been around for a long time. By incorporating these products in a thin film around the seeds their overall performance can be greatly improved and the amounts of these products needed for efficacy greatly reduced. This has a direct impact on the cost effectiveness, the protection and the final yield on the field. The advantage to the environment is huge compared to traditional field application; the chemical load of these chemicals on the environment has been reduced to almost nothing. Not only such, coloring provides a strong detection color protect for seed batch, thereby preventing the seeds are eaten by people or animals. These factors greatly influence and enhanced the application of coating technology, film coating technology soon instead of the traditional seeds spray powder and leaching plasma processing mode. Do not affect seed germination, no conglutination, seed appearance Improvement, be add agentia, and be add varieties growth-regulating substance. There is a wide range of Vegetable seeds, different moisture content. Safety seed storage has important significance of vegetable seed germination and planting quality. Only the security storage, seeds can achieve the effect of high income after planting. At present the general method of seed storage is put the seed with sacks or sacks under normal temperature stacking storage after natural drying. Seed storage affect by temperature and humidity which will change seeds' water content, made seed vigor decrease rapidly. At present the most effective way of seeds storage is put seeds in low temperature and humidity environment, which can effectively delay seeds service life. Although many studies have been done on irrigation and water resources management [5-30], but all of them have been considered classical conditions for crops. However, these conditions that include grows coefficients $\left(K_{c}\right)$ related to the evapotranspiration, water and salinity stress etc., are changed when farmers are used improved seeds. In improved seeds, required water and other water management parameters are different from initial conditions (unimproved seeds). According to that a slender difference in water requirement estimation is caused damage in agricultural productions or water losses, need to update of irrigation and water resources information according to the progresses of agricultural knowledge is very important.

\section{References}

1. Agrawal GK, Rakwal R (2012) Seed Development: OMICS Technologies toward Improvement of Seed Quality and Crop Yield. Springer, ISBN 978-94007-4748-7

2. Tuteja NG, Sarvajeet SG (2013) Crop Improvement Under Adverse Conditions Springer India, 394.

3. Reddy PP (2013) Recent advances in crop protection. Springer India, 259

4. Boopathi NM (2013) Genetic Mapping and Marker Assisted Selection. Springer India.

5. Valipour M, Banihabib ME, Behbahani SMR (2013) Comparison of the ARMA ARIMA, and the autoregressive artificial neural network models in forecasting the monthly inflow of Dez dam reservoir. Journal of Hydrology 476: 433-441.

6. Valipour M (2013) INCREASING IRRIGATION EFFICIENCY BY MANAGEMENT STRATEGIES: CUTBACK AND SURGE IRRIGATION. ARPN Journal of Agricultural and Biological Science 8: 35-43.

7. Valipour M (2013) USE OF SURFACE WATER SUPPLY INDEX TO ASSESSING OF WATER RESOURCES MANAGEMENT IN COLORADO AND OREGON, US. Advances in Agriculture, Sciences and Engineering Research 3: 631-640.

8. Valipour M (2013) Estimation of Surface Water Supply Index Using Snow Water Equivalent. Advances in Agriculture, Sciences and Engineering Research 3 . 587-602.

9. Valipour M (2013) Scrutiny of Inflow to the Drains Applicable for Improvement of Soil Environmental Conditions. In: The $1^{\text {st }}$ International Conference on Environmental Crises and its Solutions, Kish Island, Iran.

10. Valipour M (2013) Comparison of Different Drainage Systems Usable for Solution of Environmental Crises in Soil. In: The 1st International Conference on Environmental Crises and its Solutions, Kish Island, Iran.

11. Valipour M, Mousavi SM, Valipour R, Rezaei E (2013) A New Approach for Environmental Crises and its Solutions by Computer Modeling. In: The 1st International Conference on Environmental Crises and its Solutions, Kish Island, Iran.

12. Valipour M, Banihabib ME, Behbahani SMR (2012) Monthly Inflow Forecasting Using Autoregressive Artificial Neural Network. Journal of Applied Sciences 12: 2139-2147.

${ }^{*}$ Corresponding author: Mohammad Valipour, Department of Irrigation and Drainage Engineering, College of Abureyhan, University of Tehran, Iran, E-mail: vali-pour@hotmail.com

Received May 16, 2013; Accepted May 18, 2013; Published May 25, 2013

Citation: Valipour M (2013) Need to Update of Irrigation and Water Resources Information According to the Progresses of Agricultural Knowledge. Agrotechno S10: e001. doi:10.4172/2168-9881.S10-e001

Copyright: (c) 2013 Valipour M. This is an open-access article distributed unde the terms of the Creative Commons Attribution License, which permits unrestricted use, distribution, and reproduction in any medium, provided the original author and source are credited. 
Citation: Valipour M (2013) Need to Update of Irrigation and Water Resources Information According to the Progresses of Agricultural Knowledge. Agrotechnol S10: e001. doi:10.4172/2168-9881.S10-e001

Page 2 of 2

13. Valipour M, Banihabib ME, Behbahani SMR (2012) Parameters Estimate of Autoregressive Moving Average and Autoregressive Integrated Moving Average Models and Compare Their Ability for Inflow Forecasting. Journal of Mathematics and Statistics 8: 330-338.

14. Valipour M (2012) Critical Areas of Iran for Agriculture Water Management According to the Annual Rainfall. European Journal of Scientific Research 84: 600-608.

15. Valipour M, Montazar AA ( 2012) Optimize of all Effective Infiltration Parameters in Furrow Irrigation Using Visual Basic and Genetic Algorithm Programming. Australian Journal of Basic and Applied Sciences. 6: 132-137.

16. Valipour M, Montazar AA (2012) Sensitive Analysis of Optimized Infiltration Parameters in SWDC model. Advances in Environmental Biology 6: 2574-2581.

17. Valipour M (2012) Comparison of Surface Irrigation Simulation Models: Full Hydrodynamic, Zero Inertia, Kinematic Wave. Journal of Agricultural Science 4: $68-74$

18. Valipour M (2012) Sprinkle and Trickle Irrigation System Design Using Tapered Pipes for Pressure Loss Adjusting. Journal of Agricultural Science. 4: 125-133.

19. Valipour M (2012) HYDRO-MODULE DETERMINATION FOR VANAEI VILLAGE IN ESLAM ABAD GHARB, IRAN. Journal of Agricultural and Biological Science 7: 968-976.

20. Valipour M, Montazar AA (2012) An Evaluation of SWDC and WinSRFR Models to Optimize of Infiltration Parameters in Furrow Irrigation. American Journal of Scientific Research. 69: 128-142.

21. Valipour M (2012) Number of Required Observation Data for Rainfall Forecasting According to the Climate Conditions. American Journal of Scientific Research 74: 79-86.
22. Valipour M (2012) Scrutiny of Pressure Loss, Friction Slope, Inflow Velocity, Velocity Head, and Reynolds Number in Center Pivot. International Journal of Advanced Scientific and Technical Research 2: 703-711.

23. Valipour M (2012) Ability of Box-Jenkins Models to Estimate of Reference Potential Evapotranspiration (A Case Study: Mehrabad Synoptic Station, Tehran, Iran). IOSR Journal of Agriculture and Veterinary Science (IOSR-JAVS) 1: 1-11.

24. Valipour M (2012) Effect of Drainage Parameters Change on Amount of Drain Discharge in Subsurface Drainage Systems. IOSR Journal of Agriculture and Veterinary Science (IOSR-JAVS) 1: 10-18.

25. Valipour M (2012) A Comparison between Horizontal and Vertical Drainage Systems (Include Pipe Drainage, Open Ditch Drainage, and Pumped Wells) in Anisotropic Soils. IOSR Journal of Mechanical and Civil Engineering (IOSRJMCE). 4: 7-12.

26. Valipour M, Mousavi SM, Valipour R, Rezaei E (2012) SHCP: Soil Heat Calculator Program. IOSR Journal of Applied Physics (IOSR-JAP) 2: 44-50.

27. Valipour M (2012) Determining possible optimal values of required flow, nozzle diameter, and wetted area for linear traveling laterals. The International Journal of Engineering and Science (IJES) 1: 37-43.

28. Valipour M, Mousavi SM, Valipour R, Rezaei E (2012) Air, Water, and Soil Pollution Study in Industrial Units Using Environmental Flow Diagram. Journal of Basic and Applied Scientific Research. 2: 12365-12372.

29. Valipour M (2013) Necessity of Irrigated and Rainfed Agriculture in the World. Irrigation \& Drainage Systems Engineering. S9: 1-3.

30. Valipour M (2013) Evolution of Irrigation-Equipped Areas as Share of Cultivated Areas. Irrigation \& Drainage Systems Engineering. 2: 114-115. 